\title{
Pemberdayaan Kelompok Wanita Tani pada Usaha Tanaman Hias : Peningkatan Keterampilan dan Pendapatan Masyarakat
}

\author{
Kiky Nurfitri Sari ${ }^{*}$, Andika Prawanto ${ }^{2}$, Indriati Meilina Sari ${ }^{3}$, Leny \\ Maryati $^{4}$ \\ ${ }^{123}$ Akademi Komunitas Negeri Rejang Lebong \\ ${ }^{4}$ Balai Penyuluh Pertanian Selupu Rejang Kabupaten Rejang Lebong \\ E-mail*: nurfitrisarikiky@gmail.com
}

Article History: Abstrak: Desa Karang Jaya berada di

Received: Juni 2021

Revised: September

2021

Accepted: Oktober

2021

Available online:

Desember 2021

kawasan wisata Kabupaten Rejang Lebong yang memiliki potensi dalam pengembangan sumber pendapatan masyakarat. Pengembangan sumber pendapatan masyarakat dapat dilakukan melalui pemanfaatan sumber daya lokal potensial yang dikenal sebagai sumber penghasil produk pertanian khususnya pada tanaman hortikultura seperti sayuran, buah dan tanaman hias. Pengembangan potensi tanaman

Kata Kunci:

Kelompok Wanita

Tani, Keterampilan, Tanaman Hias hias melalui usaha yang dilakukan oleh Kelompok Wanita Tani (KWT) Desa Karang Jaya membuat perekonomian masyarakat setempat mulai berdampak positif pada sumber pendapatan masyarakat. Untuk menjaga stabilitas perekonomian tersebut, diperlukan keterampilan yang dapat meningkatkan nilai ekonomi produk yang dihasilkan. Kegiatan ini bertujuan memberdayakan KWT pada usaha tanaman hias dalam meningkatkan keterampilan dan pendapatan masyarakat yang dilaksanakan di Desa Karang Jaya, Kabupaten Rejang Lebong dengan tahapan seperti survei lokasi, sosialisasi terhadap sasaran kelompok, demonstrasi, monitoring, dan evaluasi. Kegiatan ini secara nyata memberikan keterampilan dan menghasilkan produkproduk lokal hasi pengembangan tanaman hias berupa suvenir lokal yang siap kepada KWT 
di Desa Karang Jaya.

\section{Pendahuluan}

Desa Karang Jaya merupakan desa yang berada di Kecamatan Selupu Rejang, Kabupaten Rejang Lebong. Desa yang terletak di sekitar "Gunung Kaba" ini terus melakukan kegiatan pembangunan di berbagai bidang. Kegiatan pembangunan merupakan pendayagunaan sumber daya (alam, buatan dan manusia) dan lingkungan sehingga harkat dan kesejahteraan masyarakat dapat meningkat. Hampir 90\% mata pencaharian masyarakat di Desa Karang Jaya adalah petani. Dikenal sebagai sentral pertanian khususnya penghasil tanaman hortikultura, Desa Karang Jaya saat ini sedang berusaha mengembangkan potensi sumber daya lokal daerah yang berkaitan dengan kebijakan pemerintah di Kabupaten Rejang Lebong. Program kebijakan tersebut dilakukan pemerintah untuk menggali potensi suatu desa melalui pengembangan inovasi ataupun penerapan teknologi tepat guna yang dapat diterapkan oleh masyarakat setempat untuk menunjang sumber pendapatan masyarakat.

Adapun salah satu program pemerintah Kabupaten Rejang Lebong yaitu mengembangkan kawasan Kecamatan Selupu Rejang menjadi daerah wisata. Program tersebut menuntut Desa Karang Jaya untuk memiliki ciri khas tersendiri yang dapat menarik minat masyarakat lokal maupun luar untuk berwisata. Selain menjadi petani sayur dan buah, saat ini Desa Karang Jaya mulai mengembangkan tanaman hias sebagai sumber mata pencarian tambahan yang dapat meningkatkan pendapatan masyarakat. Hal serupa juga dilakukan oleh Marlien et. al., (2019), yang telah memberikan pemberdayaan masyarakat pada kelompok tani bunga di Kecamatan Tonohon Utara Kota Tonohon untuk meningkatkan perekonomian masyarakat. Tanaman hias merupakan tanaman hortikultura non pangan yang dibudidayakan untuk dinikmati serta memiliki nilai estetika (Wayan, 2016).

Pengembangan tanaman hias di Desa Karang Jaya dilatar belakangi untuk eksplorasi potensi lokal daerah yang menjadi ciri khas sehingga bisa menarik minat wisatawan yang berkunjung. Saat ini, pengembangan usaha tanaman hias sudah terlihat cukup baik di Desa Karang Jaya. Beberapa KWT 
sudah mulai menekuni usaha tersebut. Namun usaha ini belum menghasilkan hasil yang optimal. Hal ini dikarenakan belum ada kegiatan pelatihanpelatihan yang diberikan pemerintah dalam meningkatkan keterampilan masyarakat terhadap pengembangan dan pengelolaan tanaman hias. Jamila et al. (2013), telah melakukan program pemberdayaan masyarakat dalam pengelolaan tanaman hias mulai dari perbanyakan tanaman hias, pembuatan biopestisida, dan penggunaan alat infuse tanah liat untuk pemeliharaan tanaman tahan kekeringan, serta penguatan pada kelompok mitra.

Oleh karena itu, diharapkan melalui kegiatan ini dapat memberikan solusi dalam pemecahan permasalahan yang dihadapi oleh beberapa KWT di Desa Karang Jaya yang sedang melakukan usaha peningkatan nilai tanaman hias. Sebagai sasaran utama dalam kegiatan ini, KWT akan diberikan suatu bentuk kegiatan pemberdayaan masyarakat yang merupakan konsep untuk pembangunan ekonomi yang dilakukan melalui keahlian kerja yang fokus pada pengembangan potensi lokal.

\section{Metode}

Kegiatan ini dilaksankan pada bulan November - Desember tahun 2019 di Desa Karang Jaya, Kecamatan Selupu Rejang, Kabupaten Rejang Lebong. Sasaran utama dalam kegiatan ini adalah KWT Krisan yang terdiri dari 20 orang peserta. Kegiatan ini dilakukan dalam beberapa tahapan. Adapun tahapan yang dilakukan yaitu :

1. Persiapan

Persiapan yang dilakukan yaitu survei lokasi. Survei lokasi merupakan kegiatan untuk mengidentifikasi masalah, potensi, dan kebutuhan suatu desa yang akan dijadikan program kegiatan. Pada tahap ini terjadi pertukaran informasi dan data mengenai potensi sumber daya dan kebutuhan sesungguhnya masyarakat sehingga keputusan program berdasarkan pada kebutuhan dan kemampuan masyarakat. Program kegiatan ini disusun untuk mengembangkan potensi desa melalui pemberdayaan masyarakat. Program kegiatan ini dimulai dari pengenalan desa sebagai desa wisata dalam konsep "Pemanfaatan tanaman hias lokal sebagai sumber pendapatan tambahan masyarakat melalui peningkatan keterampilan dalam pengelolaan tanaman hias”. 
Program ini dilakukan dengan cara memaparkan potensi yang dapat dikembangkan. Selain itu pemberdayaan masyarakat ditingkatkan melalui kegiatan pelatihan dan pendampingan hingga memfasilitasi dalam pengembangan program yang masuk ke dalam tahap pelaksanaan.

2. Pelaksanaan Kegiatan

Pelaksanaan kegiatan merupakan tahap kedua dalam kegiatan ini yang dilakukan dalam bentuk sosialisasi jadwal dan materi, pelatihan, dan pendampingan kepada kelompok sasaran di Desa Karang Jaya. Konsep tersebut dimulai dari pengenalan jenis tanaman hias, proses perbanyakannya hingga proses pembuatan produk seperti suvenir dari tanaman hias dan lainnya.

3. Monitoring dan Evaluasi

Monitoring dilakukan untuk melihat respon kelompok sasaran terhadap pemberdayaan yang telah dilakukan. Kegiatan evaluasi dilaksanakan dengan cara melihat kemajuan hasil pelatihan yang telah diberikan secara langsung. Sedangkan untuk pengambilan data dilakukan dengan pengamatan langsung, wawancara, dan kuisioner terhadap sasaran kelompok. Parameter yang amati adalah peningkatan pengetahuan dan keterampilan dalam pengelolaan usaha tanaman hias. Pengambilan data dilakukan sebelum kegiatan dilakukan dan pasca kegiatan dilakukan.

\section{Hasil}

Hasil dan capaian dari pelaksanaan kegiatan pengabdian tentang "Pemberdayaan KWT pada Usaha Tanaman Hias : Peningkatan Keterampilan dan Pendapatan Masyarakat" antara lain yaitu pada tahap awal persiapan yang dilakukan melalui kegiatan survei lokasi menunjukkan bahwa terdapat permasalahan yang dihadapi oleh kelompok sasaran. Berdasarkan permasalahan yang ditemukan, diperoleh solusi atau alternatif yang dapat dilakukan melalui program kegiatan yang akan ditawarkan kepada kelompok sasaran (Tabel 1). 
Tabel 1. Permasalahan dan solusi kegiatan

\begin{tabular}{|c|c|c|}
\hline No & Permasalahan & Solusi \\
\hline 1 & $\begin{array}{l}\text { KWT desa Karang Jaya belum } \\
\text { sepenuhnya memiliki aktivitas } \\
\text { ekonomi produktif }\end{array}$ & $\begin{array}{l}\text { Memberikan keterampilan kerja } \\
\text { berwirausaha untuk membantu } \\
\text { pendapatan keluarga }\end{array}$ \\
\hline 2 & $\begin{array}{l}\text { Sebagian besar tanaman hias } \\
\text { di desa Karang Jaya belum } \\
\text { tergali }\end{array}$ & $\begin{array}{l}\text { Memberikan pengetahuan dan } \\
\text { keterampilan tentang tanaman hias }\end{array}$ \\
\hline 3 & $\begin{array}{l}\text { Keterampilan dalam mengolah } \\
\text { tanaman hias masih rendah }\end{array}$ & $\begin{array}{l}\text { Mengolah tanaman hias menjadi produk } \\
\text { suvenir lokal }\end{array}$ \\
\hline 4 & $\begin{array}{l}\text { KWT belum mengetahui } \\
\text { prinsip marketing untuk } \\
\text { pemasaran suatu produk }\end{array}$ & $\begin{array}{l}\text { Pelatihan pengemasan, pelabelaan, dan } \\
\text { pemasaran }\end{array}$ \\
\hline
\end{tabular}

Tindak lanjut hasil survei lokasi yang dilakukan adalah melakukan sosialisasi yang merupakan bagian dari tahap pelaksanaan kegiatan. Sosialisasi dilakukan dalam bentuk pemaparan materi kepada kelompok sasaran yaitu KWT Krisan di Desa Karang Jaya. Pada kegiatan ini dihadiri oleh 12 orang dari 20 yang tergabung di dalam KWT Krisan. Adapun materi yang diberikan yaitu : (1) Sosialisasi potensi desa sebagai sentral pertanian, sosialisasi ini diberikan untuk meningkatkan pengetahuan kelompok sasaran terhadap potensi desa yang dapat dimanfaatkan sebagai peluang usaha bagi masyarakat setempat. Kegiatan ini bermaksud untuk mengangkat pertanian di Desa Karang Jaya sebagai sumber mata pencaharian yang menjanjikan. Hal ini telah dilakukan oleh Ihsaniyati et al. (2017), yang memberikan suatu program pemberdayaan masyarakat untuk meningkatkan sumber pendapatan serta kemandirian masyarakat dalam berwirausaha batik lokal yang menjadi salah satu potensi dari Kabupaten Wonogiri. (2) Sosialisasi potensi pengembangan tanaman hias, kegiatan ini dilakukan untuk mengetahui prospek pengusahan tanaman hias dalam pot (potplant) yang dapat difungsikaan sebagai tanaman outdoor maupun indoor yang memiliki nilai tinggi (Lakamisi, 2010). (3) Sosialisasi pembuatan produk dari tanaman hias, menurut Ananda et al., (2017), gabungan dari berbagai jenis tanaman hortikultura merupakan asal dari tanaman hias yang menciptakan keindahan, 
kenyamanan, serta keasrian sehingga dapat menghasilkan suatu nilai ekonomi tinggi sebagai komoditas unggulan untuk di dalam maupun luar negeri. dan (4) sosialisasi teknik pemasaran.
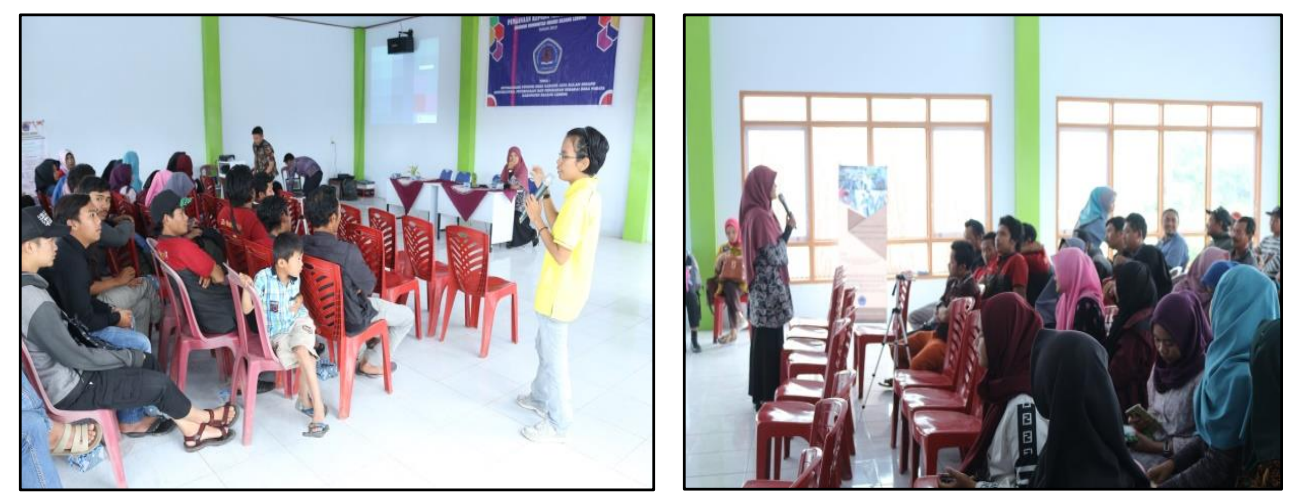

Gambar 1. Pelaksanaan sosialisasi materi kepada kelompok sasaran

Tahap selanjutnya yang dilakukan setelah sosialisasi adalah pelatihan dan pendampingan. Bentuk pelatihan dan pendampingan yang diberikan kepada kelompok sasaran adalah praktik langsung materi yang diberikan pada kelompok sasaran dalam proses pemberdayaan masyarakat. Kegiatan demonstrasi ini dilakukan dengan menyediakan narasumber dan teknisi yang mendamping kelompok sasaran selama kegiatan berlangsung. Narasumber dan teknisi mengarahkan kelompok sasaran pada cara pembudidayaan tanaman hias mulai dari proses pembibitan hingga pada tahapan pemeliharaan. Hal serupa juga telah dilakukan oleh Romadhon \& Muhtad (2018), dalam kegiatannya dimana memberikan pelatihan dalam membudidayakan Anggrek sebagai tanaman unggulan oleh POKTAN di Kota Tangerang Selatan. Selain itu, kelompok sasaran juga didampingi untuk menghasilkan suatu produk dari tanaman hias yang memiliki nilai tambah secara ekonomi seperti suvenir yang berasal dari tanaman bambu rejeki, sukulen, kaktus dan lainnya. Bambu rejeki, sukulen dan kaktus merupakan satu diantara banyaknya tanaman hias yang memiliki daya tarik bagi masyarakat. Menurut Juma'ani \& Munawwaroh (2017), bambu rejeki merupakan tanaman yang baik untuk mengatasi polusi udara sehingga memiliki manfaat lebih sebagai tanaman hias. Adapun contoh 
produk suvenir tanaman hias yang dihasilkan oleh kelompok sasaran yaitu sebagai berikut :
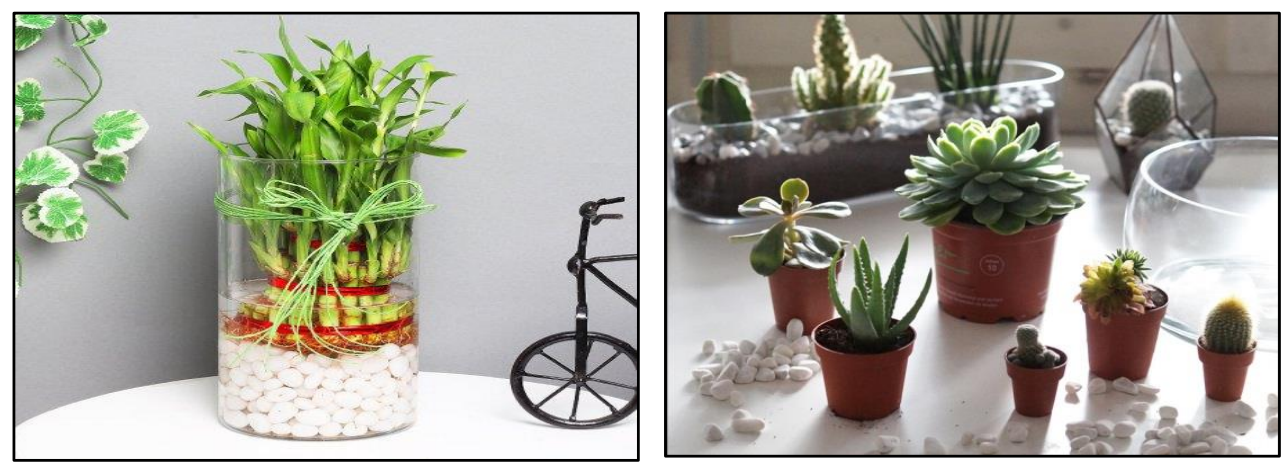

Gambar 2. Berbagai bentuk kreasi tanaman hias

Peningkatan kreativitas yang dimiliki tersebut diharapkan mampu memotivasi kelompok sasaran untuk membuat produk suvenir dari tanaman hias seperti kaktus, bambu rezeki dan sukulen sehingga terlihat artistik yang bernilai ekonomi tinggi. Adapun bahan yang perlu dipersiapkan dalam proses pembuatannya yaitu media tanam dan bibit tanaman. Media tanam yang digunakan adalah tanah, pasir, sekam, dan sejenisnya. Sedangkan untuk bibit tanaman yang digunakan berasal dari indukan tanaman (bambu rejeki, sukulen dan kaktus) yang siap untuk distek ataupun digunakan untuk proses pembibitan dengan teknik sambung (grafting) khsusnya pada kaktus. Perlengkapan yang harus disiapkan yaitu pisau, karet gelang dan pot.

Perkembangan kemampuan kelompok sasaran dilihat berdasarkan kegiatan monitoring dan evaluasi yang telah dilakukan (Tabel 2). Kegiatan monitoring merupakan kegiatan yang tujuannya untuk memberikan penghargaan kepada kelompok sasaran yaitu KWT Krisan yang berhasil mengeksplor tanaman hias sebagai usaha dalam meningkatkan pendapatan keluarga. 
Tabel 2. Kondisi kelompok sasaran pasca kegiatan

\begin{tabular}{|c|c|c|}
\hline No & Permasalahan & Pasca Kegiatan \\
\hline 1 & $\begin{array}{l}\text { KWT desa Karang Jaya belum } \\
\text { sepenuhnya memiliki aktivitas } \\
\text { ekonomi produktif }\end{array}$ & $\begin{array}{l}\text { Anggota KWT memiliki keterampilan } \\
\text { dalam pengelolaan usaha tanaman hias }\end{array}$ \\
\hline 2 & $\begin{array}{l}\text { Sebagian besar tanaman hias } \\
\text { di Desa Karang Jaya belum } \\
\text { tergali }\end{array}$ & $\begin{array}{l}\text { Tanaman hias lokal sudah mulai tergali } \\
\text { di kalangan masyarakat setempat }\end{array}$ \\
\hline 3 & $\begin{array}{l}\text { Keterampilan dalam mengolah } \\
\text { tanaman hias masih rendah }\end{array}$ & $\begin{array}{l}\text { Anggota KWT telah memiliki } \\
\text { keterampilan menjadikan tanaman hias } \\
\text { sebagai produk olahan seperti suvenir }\end{array}$ \\
\hline 4 & $\begin{array}{l}\text { KWT belum mengetahui } \\
\text { prinsip marketing untuk } \\
\text { pemasaran suatu produk }\end{array}$ & $\begin{array}{l}\text { Anggota KWT telah memiliki } \\
\text { pemahaman tentang marketing }\end{array}$ \\
\hline \multicolumn{3}{|c|}{$\begin{array}{l}\text { Hampir } 60 \% \text { seluruh anggota KWT Krisan berhasil mengusahakan } \\
\text { hias sebagai sumber pendapatan tambahannya dengan baik. Masing- } \\
\text { peserta diberikan penghargaan berupa sertifikat sebagai bentuk } \\
\text { ke depannya. Selain melakukan kegiatan monitoring secara } \\
\text { g, evaluasi juga dilakukan sebagai bentuk memperoleh data melalui } \\
\text { wawancara terhadap kelompok sasaran yaitu KWT Krisan untuk }\end{array}$} \\
\hline
\end{tabular}

\section{Diskusi}

Hasil kegiatan yang dilakukan menunjukkan terjadi peningkatan pengetahuan dan keterampilan kelompok sasaran yaitu pengetahuan tentang tanaman hias dan keterampilan dalam mengolah tanaman hias sebagai produk seperti suvenir. Adapun persentase peningkatan pengetahuan kelompok sasaran terhadap tanaman hias yaitu sebagai berikut (Tabel 3) : 
Tabel 3.Hasil program pelatihan peningkatan nilai ekonomis tanaman hias di Desa Karang Jaya Kecamatan Selupu Rejang

\begin{tabular}{|c|c|c|c|c|c|c|c|}
\hline \multirow[b]{2}{*}{ No } & \multirow[b]{2}{*}{ Pertanyaan } & \multicolumn{2}{|c|}{ Awal } & \multicolumn{2}{|c|}{ Akhir } & \multicolumn{2}{|c|}{$\begin{array}{c}\text { Persentase } \\
\text { Pengetahuan }(\%)\end{array}$} \\
\hline & & Ya & $\begin{array}{l}\text { Tid } \\
\text { ak }\end{array}$ & $\mathbf{Y a}$ & $\begin{array}{l}\text { Tid } \\
\text { ak }\end{array}$ & $\begin{array}{l}\text { Sebelum } \\
\text { Pengabdi } \\
\quad \text { an }\end{array}$ & $\begin{array}{l}\text { Setelah } \\
\text { Pengabdi } \\
\text { an }\end{array}$ \\
\hline 1 & $\begin{array}{l}\text { Apakah Anda tahu } \\
\text { tentang tanaman } \\
\text { hias }\end{array}$ & 12 & 0 & 12 & 0 & 100 & 100 \\
\hline 2 & $\begin{array}{l}\text { Apakah Anda tahu } \\
\text { jenis-jenis tanaman } \\
\text { hias }\end{array}$ & 9 & 3 & 12 & 0 & 75 & 100 \\
\hline 3 & $\begin{array}{l}\text { Apakah Anda tahu } \\
\text { manfaat tanaman } \\
\text { hias }\end{array}$ & 10 & 2 & 11 & 1 & 83,3 & 91,7 \\
\hline 4 & $\begin{array}{l}\text { Apakah Anda tahu } \\
\text { bentuk kaktus }\end{array}$ & 9 & 3 & 10 & 2 & 75,0 & 83,3 \\
\hline 5 & $\begin{array}{l}\text { Apakah Anda tahu } \\
\text { bentuk bambu } \\
\text { rejeki/bambu hoki }\end{array}$ & 10 & 2 & 10 & 2 & 83,3 & 83,3 \\
\hline 6 & $\begin{array}{l}\text { Apakah Anda tahu } \\
\text { bentuk sukulen }\end{array}$ & 4 & 8 & 8 & 4 & 33,3 & 66,7 \\
\hline 7 & $\begin{array}{l}\text { Apakah Anda tahu } \\
\text { media tanam untuk } \\
\text { kaktus }\end{array}$ & 6 & 6 & 10 & 2 & 50 & 83,3 \\
\hline 8 & $\begin{array}{l}\text { Apakah Anda tahu } \\
\text { media tanam untuk } \\
\text { bambu rejeki }\end{array}$ & 10 & 2 & 12 & 0 & 83,3 & 100 \\
\hline 9 & $\begin{array}{l}\text { Apakah Anda tahu } \\
\text { media tanam untuk } \\
\text { sukulen }\end{array}$ & 1 & 11 & 9 & 3 & 8,3 & 75 \\
\hline 10 & $\begin{array}{l}\text { Apakah Anda bisa } \\
\text { membuat kaktus } \\
\text { dalam pot }\end{array}$ & 1 & 11 & 8 & 4 & 8,3 & 66,7 \\
\hline
\end{tabular}




\begin{tabular}{|c|c|c|c|c|c|c|c|}
\hline 11 & $\begin{array}{l}\text { Apakah Anda bisa } \\
\text { membuat/merangk } \\
\text { ai bambu rejeki } \\
\text { dalam pot }\end{array}$ & 1 & 11 & 9 & 3 & 8,3 & 75 \\
\hline 12 & $\begin{array}{l}\text { Apakah Anda bisa } \\
\text { membuat sukulen } \\
\text { dalam pot }\end{array}$ & 0 & 12 & 9 & 3 & 0 & 75 \\
\hline 13 & $\begin{array}{l}\text { Apakah Anda tahu } \\
\text { cara memelihara } \\
\text { kaktus }\end{array}$ & 0 & 12 & 10 & 2 & 0 & 83,3 \\
\hline 14 & $\begin{array}{l}\text { Apakah Anda tahu } \\
\text { cara memelihara } \\
\text { bambu rejeki }\end{array}$ & 2 & 10 & 12 & 0 & 16,7 & 100 \\
\hline 15 & $\begin{array}{l}\text { Apakah Anda tahu } \\
\text { cara memelihara } \\
\text { sukulen }\end{array}$ & 0 & 12 & 10 & 2 & 0 & 83,3 \\
\hline 16 & $\begin{array}{l}\text { Apakah menurut } \\
\text { anda kegiatan ini } \\
\text { bermanfaat }\end{array}$ & 12 & 0 & 12 & 0 & 100 & 100 \\
\hline
\end{tabular}

Berdasarkan tabel di atas, secara umum hasil kegiatan yang dilakukan menunjukkan bahwa :

1. Keberhasilan target jumlah peserta pelatihan

Keberhasilan target jumlah peserta pelatihan dapat dikatakan kurang baik. Target jumlah peserta pelatihan sebanyak 20 orang dan dalam pelaksanaan pengabdian hadir sebanyak 12 orang $(60 \%)$.

2. Ketercapaian tujuan pelatihan

Ketercapaian tujuan pelatihan dapat dikatakan baik. Kegiatan pengabdian ini berhasil memberdayakan ibu-ibu rumah tangga dan remaja putri di lokasi pengabdian dengan membuat berbagai jenis kerajinan tangan dari tanaman kaktus, bambu rejeki dan sukulen. Ada beberapa capaian yang masih kecil yaitu pengetahuan tentang sukulen $(66,7 \%)$ yang peserta masih bingung membedakan antara tanaman kaktus dengan sukulen dan masalah tentang penyambungan kaktus dalam pot $(66,7 \%)$ yang masih belum mengerti tentang tata cara 
menyambung antara batang bawah dengan batang atas.

3. Ketercapaian target materi yang telah direncanakan

Ketercapaian target materi yang telah direncanakan dapat dikatakan baik. Semua materi pelatihan dapat disampaikan secara keseluruhan melalui media tulisan, foto dan video tata cara pembuatan suvenir.

4. Kemampuan peserta dalam penguasaan materi

Kemampuan peserta dalam penguasaan materi dapat dikatakan baik. Hal ini didukung penggunaan metode ceramah, pemberian visualisasi baik photo maupun video serta demonstrasi langsung untuk meningkatkan kemampuan peserta pelatihan dalam menyerap materi yang disampaikan oleh narasumber.

Secara keseluruhan kegiatan pelatihan peningkatan nilai tambah secara ekonomi tanaman hias di Desa Karang Jaya Kecamatan Selupu Rejang Kabupaten Rejang Lebong dinilai cukup berhasil. Keberhasilan ini selain diukur dari keempat komponen di atas, juga dapat dilihat dari kepuasan peserta setelah mengikuti kegiatan pelatihan. Manfaat yang dapat diperoleh para peserta pelatihan adalah pengetahuan dan keterampilan dalam mengolah tanaman kaktus, bambu rezeki dan sukulen menjadi produk tanamn hias yang artistik dan bernilai ekonomi tinggi. Pasca pelaksanaan kegiatan ini, kelompok sasaran memiliki produk tanaman hias yang layak dipasarkan yaitu suvenir lokal. Selain itu, pengetahuan tentang marketing diharapkan mampu meningkatkan pendapatan keluarga secara bertahap. Dalam penelitian yang dilakukan oleh Rahmanto \& Ismarani (2018), bahwa rata-rata minat masyarakat akan mengalami penurunan terhadap pengelolaan usaha di bidang tanaman hias akibat kurangnya pengetahuan dan rasa percaya diri terhadap produk yang dihasilkan. Namun hasil penelitian yang dilakukan oleh Wulandari (2020), bahwa penerapan strategi usaha tanaman hias sukulen dalam manajemen pemasaran dapat memberikan keuntungan bagi pedagang sebagai kekuatan dan peluang dalam menghadapi kelemahan dan ancaman di dalam pengembangan usaha tanaman hias. 


\section{Kesimpulan}

Program pemberdayaan ini telah menjadikan KWT Krisan memiliki pengetahuan dan keterampilan dalam usaha tanaman hias. Kegiatan ini dapat menjadi sumber pendapatan tambahan bagi masyarakat dalam membantu perekonomian keluarga. Selain itu, keterampilan yang diberikan dapat meningkatkan nilai tambah suatu produk secara ekonomi di masa mendatang.

\section{Pengakuan/Acknowledgements}

Terimakasih kepada Pusat Penelitian, Pengabdian kepada Masyarakat, dan Penjaminan Mutu (P3M-PM) Akademi Komunitas Negeri Rejang Lebong atas bantuan untuk pelaksanaan kegiatan pengabdian kepada masyarakat tahun anggaran 2019 berdasarkan kontrak dengan Nomor : 188/AK4/KP.11.00/2019. Terimakasih kepada Desa Karang Jaya Kecamatan Selupu Rejang Kabupaten Rejang Lebong atas kerjasamanya sehingga kegiatan pengabdian kepada masyarakat dapat dilaksanakan.

\section{Referensi}

Ananda, P.A., Tetty W., \& Nella, N.D. (2017). Analisis Strategi Pengembangan Usaha. Jurnal Ekonomi Pertanian \& Pembangunan, 14(1), 46.

I Wayan, W. (2016). Teknologi Budidaya Tanaman Hias. In Fakultas Pertanian Unud. Ihsaniyati, H., Wijianto, A., Suminah, S., \& Anantanyu, S. (2017). Pemberdayaan Kwtpada Usaha Batik Tulis: Upaya Peningkatan Pendapatan Dan Kemandirian. E-Dimas, 8(1), 44.

Jamila., Zulfitriany, D.M., Dan Suriani. (2013). Ibm Kelompok Tani Tanaman Hias Di Makassar. 83740(May), 27-31.

Juma'ani, J., \& Munawwaroh, A. (2017). Analisis Karakteristik Stomata Pada Daun Tanaman Bambu Rejeki (Dracaena Reflexa) Sebagai Tanaman Hias Penyerap Polusi Di Kawasan Kota Malang. Edubiotik : Jurnal Pendidikan, Biologi Dan Terapan, 2(02), 7-12.

Lakamisi, H. (2010). Prospek Agribisnis Tanaman Hias Dalam Pot (Potplant). Agrikan: Jurnal Agribisnis Perikanan, 3(2), 55.

Rahmanto, M., Khwan., \& Ismarani. (2018). Strategi Pengembangan Bisnis Tanaman Hias Di Kelurahan Mustikasari Kota Bekasi. The National Conferences Management And Business, 221-245.

Romadhon, S., \& Muhtadi, M. (2018). Pemberdayaan Masyarakat Melalui Kelompok Tani (Poktan) Tanaman Anggrek Parakan Jaya Kota Tangerang Selatan. Jurnal Agribisnis Terpadu, 11(2), 152.

Tulung., Marlein, A.W.V.V., Rantung, M.T. (2019). Pemberdayaan Ekonomi Masyarakat Kelompok Tani Bunga Di Kecamatan Tomohon Utara Kota 
Tomohon. Journal Of Chemical Information And Modeling, 53(9), 1689-1699. Wulandari, H. (2020). Strategi Pengembangan Usaha Tanaman Hias Sukulen (Studi: Jl. Adam Malik, Kawasan Glugur By Pass, Kota Medan Sumatera Utara). 